\title{
Antibacterial and antiviral treatment in COVID-19 patients
}

Hasan Gozdas ${ }^{1}$

${ }^{1}$ Affiliation not available

September 9, 2020

\begin{abstract}
I read the recently appeared article in your journal by Atalla et al. entitled "Readmissions among Patients with COVID-19" with great interest. In their study, 19 patients previously diagnosed with COVID-19 were readmitted within 30 days after discharge. I think that there are a few questionable points in this study.
\end{abstract}

\section{Hosted file}

title page.doc available at https://authorea.com/users/357690/articles/480118-antibacterialand-antiviral-treatment-in-covid-19-patients

\section{Hosted file}

letter . docx available at https://authorea. com/users/357690/articles/480118-antibacterial-andantiviral-treatment-in-covid-19-patients 